\author{
Julita Markiewicz-Patkowska \\ $\mathrm{PhD}$ \\ WSB University in Wrocław, Wrocław, Poland \\ ORCID ID 0000-0003-4408-5387 \\ julita.markiewicz-patkowska@wsb.wroclaw.pl

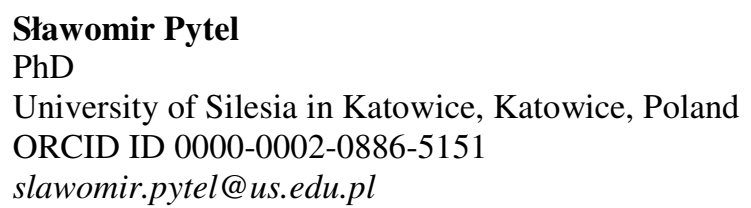

Piotr Oleśniewicz

$\mathrm{PhD}$, Assistant Professor

University School of Physical Education in Wrocław, Wrocław, Poland

ORCID ID 0000-0002-0426-0630

piotr.olesniewicz@awf.wroc.pl

\title{
Krzysztof Widawski
}

$\mathrm{PhD}$, Assistant Professor

University of Wrocław, Wrocław, Poland

ORCID ID 0000-0001-6223-3860

krzysztof.widawski@uwr.edu.pl

\section{THREE-DIMENSIONAL PHOTOGRAPHY AS A NEW TECHNIQUE TO MAKE DIDACTIC PRESENTATIONS MORE ATTRACTIVE}

\begin{abstract}
In the 21st century, the form of presenting information plays an incredibly important role in arousing interest in research problems. Stereoscopy is among the imaging techniques that have evoked much interest in the recent years. Its numerous applications that can be observed in various fields (such as medicine, space science, law, marketing, or entertainment industry) suggest that we should also use this technology for didactic purposes. The aim of the article is to discuss the process of creating threedimensional photography and the opportunities offered by stereoscopy, which makes it possible to obtain images with depth effect and impression of solidity. The authors describe different ways to obtain threedimensional images and the devices applied in the process, as well as techniques of presenting threedimensional material to a wider audience. The methods of free-viewing (the oldest method of viewing stereoscopic images), anaglyph (a simple method applied in printing and displaying static images and movies on screen), lenticular raster (employing a series of narrow vertical cylindrical lenses), and stereoscopy (in which mirrors, lenses, prisms, or filters are used) are discussed. Also, the application of computer technology is reviewed and the ways in which stereoscopy can benefit from this medium owing to the use of LCD shutter glasses. Contemporary technology offers considerable opportunities, at the same time posing ever-increasing demands, which are mentioned in the paper, too. Teaching is most effective when information is received through multiple channels, combining verbal and visual messages. Owing to 3D images, the recipients grasp more information details, remember them longer, and are more interested in the message content. Creating didactic presentations with the use of three-dimensional photographs or films is presented as a way of arousing interest, allowing direct participation in the cognitive process, and facilitating the reception of the transmitted content.
\end{abstract}

Keywords: three-dimensional image; depth effect; stereoscopy; free-viewing; anaglyph; lenticular raster; didactic presentation.

\section{INTRODUCTION}

Modern technology provides opportunities to make the presented didactic issues more attractive. The development in imaging techniques in the recent years has led to an outburst of interest in stereoscopy. Three-dimensional visualizations can be seen everywhere around us. Medical 3D systems are routinely applied in surgery and diagnostics. 3D movies shown in IMAX cinemas and amusement parks are a usual part of entertainment industry. The NASA space agency transmitted 3D images from Mars. Stereoscopic video cameras assist in steering unmanned rescue, exploration, and repairing vehicles. Lawyers employ this technology in courtrooms, real estate 
agents use it to sell houses, and many companies attract customers to their stands at fairs with it. Many three-dimensional television systems have been developed, and receivers are available worldwide.

All this suggests that we should also use this technology for didactic presentations to be able to better participate in cognition.

The aim of the article is to present the process of creating three-dimensional images, as well as to show the opportunities offered by the modern technology for the process of education and didactics.

Discovering the world consists primarily in perception. It is a multifaceted psychological mechanism that allows us all to familiarize with the surrounding reality. This is achieved mainly through sensory receptors. Inference also plays an important role, enabling to employ all the information that we have gained through experience. Not all of us perceive identical objects in the same way. It also happens that the objects that we observe are not the same as we see, and differences may arise both at the level of stimuli receptors and during the process of drawing conclusions about the object [1].

Discovering the modern world's attractions is becoming easier and easier thanks to television and computers. Many scientific disciplines make use of the capabilities of computer technology [2]. Scientists working in the geological field could be an example: Nita et al. [3], Piotrowska et al. [4], Thorleifson et al. [5]. They apply three-dimensional techniques to visualize the relief and interpret geological structures. The geovisualization method, which arose in the early 1990s, has become very popular since. Maps are considered to be tools for understanding spatial relationships. Geovisualization involves a view of a map as a certain stage in the course of a research process or in solving practical spatial problems. Today, information about the relief and natural environment is visualized on thematic maps (referring to geology, soil, geomorphology, hydrography, vegetation, climate, sozology, land cover, and land use): two-dimensional (2D), pseudo-three-dimensional (2.5D), three-dimensional (3D), and four-dimensional animated (4D) ones [6]. These techniques are also used in other branches of science. In particular, Domka [7] indicated the possibility of applying three-dimensional images in learning biology.

\section{PRESENTATION METHODS: THEORETICAL SCOPE}

Stereoscopy is among the methods allowing presentation of images with the opportunity to see the depth and location of an object in space.

Stereoscopy consists in generating images that reproduce the effect of binocular vision to provide a natural impression of depth in the scene and the solidity of objects. Many stereoscopic techniques exist, but they all boil down to presenting slightly different images to each eye (which reflects the different points of view of the right and left eye). Out of these two images, the human brain (owing to very complex mental processes) produces one three-dimensional image, with all the depth and reality of the original.

For this purpose, a pair of simple two-dimensional images are taken (a stereo pair) representing an object or scene as perceived from two viewpoints, located at the distance between the observer's eyes. The images of the stereo pair are very similar, but they differ slightly in the angle of viewing the objects and the details of their mutual veiling. These minor differences carry the information about the third dimension [8].

The beginnings of stereoscopy date back to the mid $-19^{\text {th }}$ century, although even earlier cases had been reported of people who tried eye training for their own use to enable overlapping of images of similar objects, which gave extraordinary effects of depth and solidity. 3D imaging techniques gained popularity immediately after the birth of photography at the end of the $19^{\mathrm{th}}$ century. Then, all the basic ways of obtaining 3D images were invented. The recent years have brought another explosion of interest in stereoscopy. This was made possible by the development of imaging techniques and the exchange of information via the Internet. New techniques of watching three-dimensional images appeared, with anaglyph at the forefront. 
Anaglyph 3D is a type of drawing or stereoscopic photography that creates an illusion of three-dimensionality when viewed with special two-colour (usually red and cyan) glasses. Anaglyphs are prepared by superimposing two images taken with a slight horizontal offset, corresponding to the left and right eye images [9].

In fact, there is a huge difference between a stereoscopic image and an anaglyph. Unlike anaglyphs, stereoscopic images are not superimposed on top of each other, but arranged next to each other. In addition, the images that make up the stereo pair are not identical, and the differences are fundamental to three-dimensionality. Anaglyph images are slightly horizontally displaced so that both eyes can see the image. However, some complements in cyan and red colours are visible, and the image is very blurred. On putting on three-dimensional glasses, one will see a surprising effect of a spatial image. The secret behind consists in blue or green and red filters. The brain receives one image from each eye, and the images differ in colour. The left eye perceives the image isolated at the left side, and the right eye sees the image from the right side. As a result, an illusion is created, called three-dimensionality.

\section{HOW THREE-DIMENSIONAL IMAGES ARE CREATED}

In the process of looking, each eye sees a different image, and the brain constructs one threedimensional image on the basis of the differences in these images.

To present this phenomenon in a photographic process, two slightly different images need to be created and presented to each eye, as would be seen by the eye when observing a real spatial object (Figure 1).

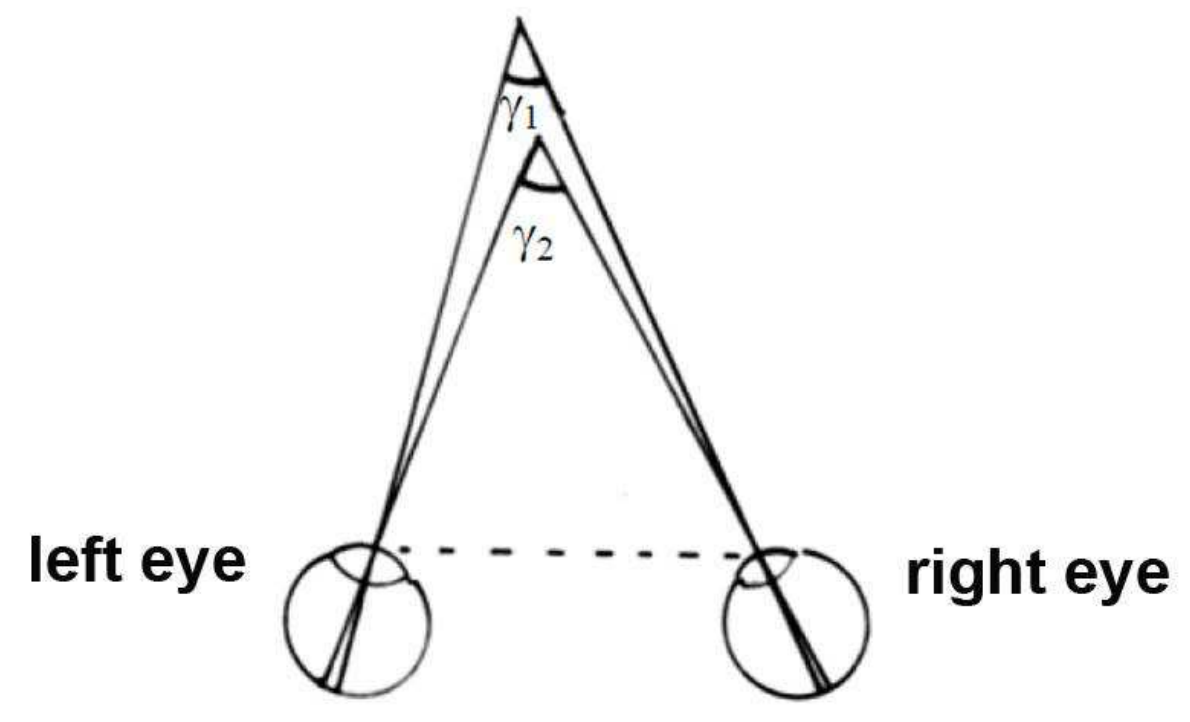

Figure 1. Measuring the resolving power in stereoscopic vision. Source: [10]

A stereo pair is prepared, i.e. two photographs are placed next to each other (one for the right and one for the left eye). To combine them into a three-dimensional picture, one can use various instruments, including lenticular stereoscopes, prismatic stereoscopes, or mirror stereoscopes; or project images onto a special screen to view them through polarizing eyepieces.

\section{HOW TO OBTAIN A THREE-DIMENSIONAL PHOTOGRAPH}

To capture a three-dimensional photograph, one needs to take two pictures from two points that are as far apart as the eyes of an observer, i.e. about $65 \mathrm{~mm}$. 
There are three techniques of taking stereoscopic photographs:

- using a special stereoscopic camera equipped with two separate lenses;

- combining two identical cameras;

- taking two separate photos with one camera, with an appropriate offset.

In the case of still subjects, one camera is needed that will move horizontally by approximately $65 \mathrm{~mm}$ after taking the first picture to take the second shot. Different methods of camera shifting can be applied, but it is essential to maintain the horizontal orientation and the same viewing direction during this process. The simplest method consists in tilting the body by shifting its weight from one leg to another between the two shots, while the camera is held close to the face. One can also move a camera resting on a table or a simple railing. The ideal solution is to use a precise camera slider mounted on a stable tripod. The single-camera approach is well suited to stilllife, unmanned architecture, static landscapes, or anthropogenic tourist attractions.

The method cannot be applied, however, for moving scenes, because in that case, the photographs need to be taken simultaneously. A factory-made stereoscopic camera is the best solution. There are both simple, compact amateur cameras and expensive premium ones available. Various sets of two identical, firmly joined, and well synchronized standard cameras can serve as an alternative to a factory-made stereo camera.

Simultaneous triggering of the shutters can be achieved in many ways. The simplest cameras can be triggered by pressing both snapshots simultaneously with two hands. Cameras equipped with a socket for the shutter release cable can be triggered with a double cable. The ideal solution is to trigger both cameras simultaneously using an electronic control system. Other options are various types of adapters for typical cameras, usually regular reflex cameras. These adapters use high quality prisms and/or mirrors to direct to a conventional lens two component images, seen from points away from each other, typically of stereoscopy, by approximately $65 \mathrm{~mm}$.

\section{HOW TO VIEW STEREO-3D IMAGES}

It is much easier to take a stereo picture than to view it or present it to a wider audience. All presentation methods involve separating the stereo pair images and showing the right image to the right eye only and the left image to the left eye only. In some methods, these images remain constantly separated (e.g. slides seen in a slide viewer); in others, they can be mixed on the same presentation surface and somehow optically or temporally filtered.

\subsection{Free-viewing}

The oldest method of viewing stereoscopic images is free-viewing, used by the inventor of the stereoscope himself, Sir Wheatstone. Afterwards, a number of stereoscopes and optical instruments were invented to enable viewing properly prepared stereo pairs.

\subsection{Anaglyph}

Another very early invention was the anaglyph method, consisting in printing the right image with red ink and the left image with blue or green ink (Figure 2). The viewer wore glasses fitted with a red glass on the left eye and a blue (or green) glass on the right eye. In this way, each eye could see only the image intended for it, and the viewer could perceive the image as stereoscopic. Thanks to its simplicity, the method was applied both for printing and for displaying not only static images, but also full-length movies on screen. 

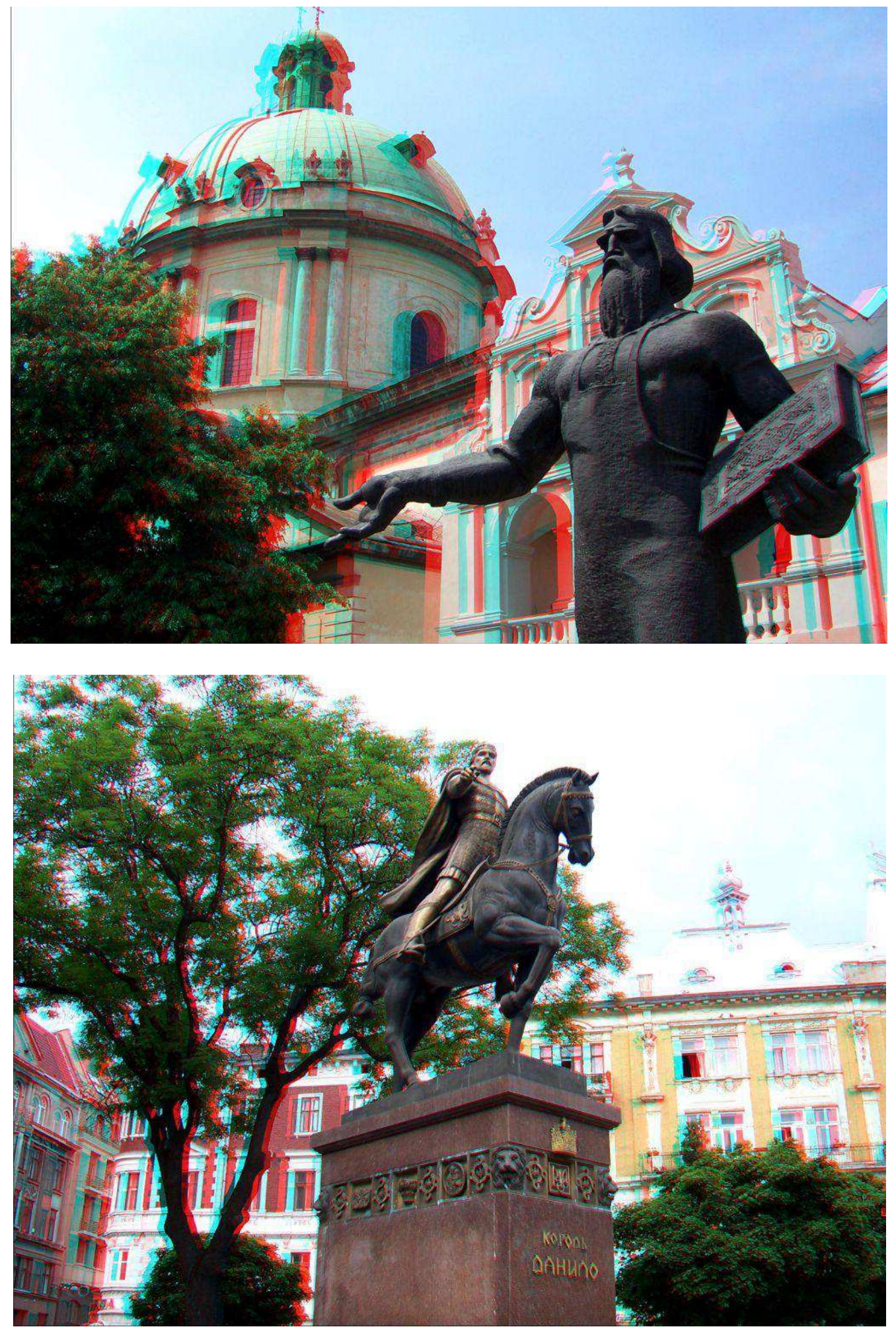

Figure 2. Examples of anaglyph photograph. Source: S. Pytel, own elaboration

\subsection{The lenticular-raster method}

The lenticular-raster method is an interesting technique of presenting three-dimensional images, which does not require from the viewer anything but normal viewing. It uses an image that is specially crafted and covered with a layer of thin material, embossed in a series of narrow vertical cylindrical lenses. As a result, each eye can only see the appropriate vertical stripes of image intended for it, and the viewer has the impression of three-dimensionality. 


\subsection{Computer}

It is a sign of the times to use computers for everything; stereoscopy also benefits from this medium. Besides the possibility to display static stereo images, prepared to be perceived with the methods of free-viewing, anaglyphs, or stereoscopes, computers also enable the display of stereoscopic films and 3D games thanks to the use of LCD shutter glasses [8].

\subsection{Stereoscopes}

A stereoscope is basically any optical device designed to view stereograms, whether it uses mirrors, lenses, prisms, or filters (Figure 3). Stereoscopes present to each eye only the image intended for it, and, as a result, give a subjective feeling of solidity and depth. In practice, this notion is not applied for simple glasses with colour or polarizing filters or for LCD glasses, but only with reference to optical systems.

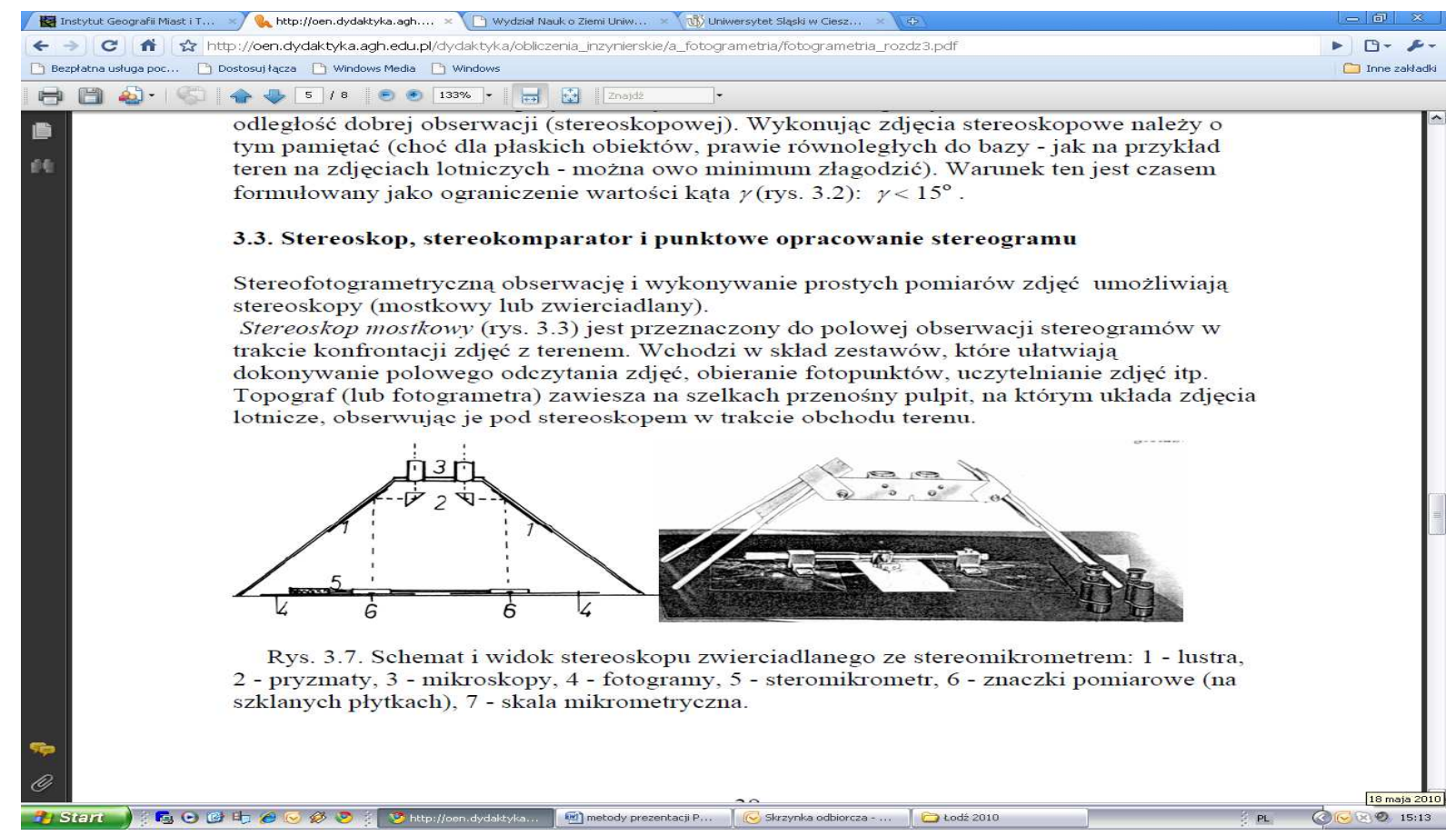

Figure 3. Diagram and view of a mirror stereoscope with a stereo-micrometer: 1 - mirrors, 2 prisms, 3 -microscopes, 4 - photograms, 5 -stereo-micrometer, 6 -measuring marks. Source: [10]

Historically, the first stereoscopes were mirror stereoscopes invented by Sir Charles Wheatstone. Owing to two mirrors placed diagonally before the observer, each eye sees only one image, which is intended for it. A variation of the instrument is the Cazes stereoscope, with two more mirrors added on the sides, so that the left and right images remain side by side and can be combined into a permanent pair. The device is easy to make, but cumbersome to use.

In a Holmes stereoscope, the lenses are connected to the prisms in such a way that the prisms change the viewing direction of each eye (so that each eye only sees its 'own' image) and the lenses slightly magnify the image. From simple, hand-held eyepieces to stunning achromatic viewers, there are many variations of stereoscopes. Depending on the type, they can be used for any flat stereo pair or only for loose stereoscopic cards or images. A simplified version of the Holmes stereoscope, hand-held prismatic glasses, enable viewing parallel stereo pairs included in books and magazines, with a base up to $8 \mathrm{~cm}$. All stereo slide viewers, both the simplest versions (made of a single piece of plastic and using ambient light) and the exclusive ones (with achromatic optics; 
focus and eyepiece spacing adjustment; and an independent illuminator with adjustable colour temperature), are also stereoscopes [8].

\section{SLIDE PRESENTATIONS}

Today, there are many ways to capture stereo images. Colour diapositives, that can be viewed in stereoscopic viewers, exhibit the highest quality. However, colourful stereo slides projected on a big screen turn out the most impressive. A long-established method, also applied in popular IMAX cinemas, namely polarized image separation, is used here. The audience, equipped with polarizing glasses, watch high-resolution, colour slides projected from a dual-lens projector onto a special, metalized screen; an ordinary one would change the light polarization, causing loss of threedimensionality as a result.

While such a show is easy to receive for the audience, its arrangement may pose a real challenge. Slides projected onto a large screen must be positioned with a precision of more than $1 / 10 \mathrm{~mm}$. This requires a special device or a lot of skill and patience. The same applies to the setup of two identical projectors (or one specialized double projector) [8].

Another way of presenting stereograms which is particularly useful in the didactic process is applying computers; they have an additional valuable feature of enabling complex image processing. Thanks to the still improved monitor performance, stereo viewing on a computer is increasingly becoming a viable alternative to paper images. Computer images, after being converted into anaglyphic form, can also be displayed with the use of ordinary multimedia projectors in a darkened room. Actually, this is the easiest way for preparing and presenting images during classes on tourist attractions.

\section{THE USE OF 3D TECHNOLOGY FOR LEARNING}

The application of 3D technology in learning is widespread today. On one hand, representatives of engineering, medical, biological, IT, and life sciences express their interest in it; on the other, it is used by psychologists, pedagogues, sociologists, philosophers, and some artists.

According to Wieczorkowski [11], 3D visualization plays an invaluable role in computer implementation in science and didactics. Owing to the intensive development of multimedia presentation tools, 3D visualization is more and more often come across even in primary schools. The graphic software being now implemented in the Polish schools provides the teacher and the student with appropriate instruments to develop graphics, prepare multimedia presentations, and model spatial geometry. The combination of 3D animation and virtual reality technology is a powerful educational tool, which may revolutionize the computer-aided learning systems. These two can present phenomena and processes in realistic conditions, resembling the actual environment.

Applying 3D didactic means activates new stimuli in the didactic process, thus increasing the perception level, and developing imagination, sensitivity, and reflection. This widens the sphere of creative didactic visualization [12]. At the same time, the impact of using these methods reaches far beyond the educational process itself, being of great significance in the general cultural development of an individual. A computer reconstruction of the real environment in a 3D space allows to reflect phenomena, events, situations, or even behaviours in a form similar to the real one.

At school, the opportunities to develop the ability to perceive space in a way other than looking at it have been scarce so far. It was very difficult to present models that would stimulate the students' spatial imagination. Many pupils, or even university students, graduated with no sense of spatial vision and with poorly developed spatial imagination.

Nowadays, it is hardly possible to think of teaching without the application of 3D computer graphics tools or virtual reality technology. There are many possible implementations of virtual instruments in this realm. Wieczorkowski [11] suggests that these may include virtual development 
of non-existent monuments of history. An example could be a restoration of the non-existent part of the abbey of Cluny in France. The church, erected in 1110, was the largest facility of this type in Europe; its body was 110 meters long and 10 storeys high. It was destroyed during the French Revolution. Now, the abbey has been reconstructed by IT specialists from the French department of IBM. The external appearance and interior design have been determined. The opportunities of virtual reality allowed restoring the former look. In the first place, a skeleton model of the church was developed. Then, owing to the preserved transept fragments, the whole building was modelled. Other examples of visualizations created by the same company include a 3D reconstruction of the destroyed Roman thermal baths in Paris and Dresden cathedral. The virtual space of the cathedral can be visited similarly to the real one.

As Poston and Serra [13] point out, much developmental effort is taken by numerous specialist workgroups. Known are interesting projects of travel to the interior of the human body, and many other visualizations within the realm of medicine. Multimedia have been implemented in medical science in a number of ways, e.g. in anatomical atlases presenting individual organs, their descriptions, function simulations, and disease entities, as well as in medical dictionaries. In Germany, according to Bayarri et al. [14], one of the remarkable industrial applications of virtual reality that arouse great interest is a system for shaping space. Of significant importance are also driving, flight, or skiing simulators.

The effectiveness of cognition is determined by attention processes. Psychologists agree that out of everything that happens around, man becomes aware only of what they focus their attention on. Thus, a condition for remembering any information (message or skill) is to concentrate and maintain attention on the stimuli that carry it. Each type of message is characterized by specific possibilities to stimulate attention processes, which should be remembered when implementing educational media. Jędryczkowski [15] emphasizes that in the traditional message, information reaches the student on two levels: substantial and nonverbal. A situation, though, in which the student enters 3D interactions brings huge potential. At the University of Rzeszów in Poland, in the e-learning office of the Laboratory for Information Society Issues of the Centre of Innovation and Technical and Biological Knowledge Transfer, five short didactic films have been created in 3D technology regarding the construction and operation of technical equipment. The films are assumed to support teaching through a longer stimulation of attention processes.

Also, interactive computer programs (Cabri II and Cabri 3D) are being created that support teaching mathematics, especially geometry: Euclidean geometry and analytic geometry in particular.

As Postawa [16] indicates, augmented 3D reality is an efficient technology for teaching and learning, as it helps obtain knowledge and skills bound with complex theories or operation mechanisms of machines and systems. Liarokapis et al. [17] indicate Australian research on an augmented reality 3D model in four realms of mechanical engineering: machines, vehicles, Platonic solids, and utensils. In Tokyo, a handbook has been published of 3D operation on smartphones, which presents the application of iPad in learning foreign languages, literature, or fine arts.

Augmented 3D reality has a considerable potential to share contextual experiences and unexpected discoveries in the real world. Location-related applications lead to teaching based on discoveries. People visiting historic places can obtain access to $3 \mathrm{D}$ applications that provide information on the appearance of these places in the past.

When learning astronomy, students widen their knowledge on the relations among planets and stars with the use of 3D technology. The SkyMap application implements information on stars and constellations obtained with GPS and compasses. Sky maps can be viewed on smartphone screens.

In their research on adult people's attention, Kasworm and Pike [18] suggest that an average adult individual can listen with understanding for ca. 90 minutes and store the transmitted content in the memory for ca. 20 minutes. As Gawlik-Kobylińska [19] maintains, a teaching module should not last longer than 90 minutes; its pace should change at least once every 20 minutes, and the way of participants' involvement - every 8 minutes. Therefore, designing shorter forms of activity is 
advised; examples could be lectures complemented by interactive elements or activities in 3D space. Such measures provide an opportunity to better understand and remember the content.

\section{CONCLUSIONS}

In the 21st century, the form of presenting information plays an incredibly important role in arousing interest in research problems. Contemporary technology offers considerable opportunities, at the same time posing ever-increasing demands. We should put off writing with chalk on a board or using transparencies; concentration on the maximally virtual means of conveying the message is strongly advised. Attractive photographs or films allow direct participation in the cognitive process.

Teaching is most effective when information is received through multiple channels, combining verbal and visual messages. Owing to 3D images, the recipients grasp more information details, remember them longer, and are more interested in the message content.

\section{REFERENCES (TRANSLATED AND TRANSLITERATED)}

[1] Młodkowski, J. (1998). Visual activity of man. Warszawa - Łódź: PWN (in Polish).

[2] Cyganek, B. (2002). Computer processing of three-dimensional images. Warszawa: Exit (in Polish).

[3] Nita, J., Małolepszy, Z., \& Chybiorz, R. (2007). Application of a numerical terrain model for the visualisation of relief and interpretation of geological structure. Przegl Geol, 55(6), 511-520 (in Polish).

[4] Piotrowska, K., Ostaficzuk, S., Małolepszy, Z., \& Rossa, M. (2005). The numerical spatial model (3D) of geological structure of Poland - from $6000 \mathrm{~m}$ to $500 \mathrm{~m}$ b.s.l. Przegl Geol, 53(10/2), 961-966 (in English).

[5] Thorleifson, H., Berg, J., Tipping, R.G., Malolepszy, Z., Harris, K.L., Lusardi, B.A., Setterholm, D.R., \& Anderson, F.J. (2005). 3D geological modeling in support of ground water inventory in the Fargo-Moorhead region, Minnesota and North Dakota. Geol Surv Canada, 5048, 97-100 (in English).

[6] Geowizualizacja 3D.[online]. Available: http://geo3d.us.edu.pl (accessed on Aug 28, 2018) (in Polish).

[7] Domka, L. (1986). Applying three-dimensional images in teaching and learning biology. Poznań: UAM (in Polish).

[8] STEREOS.[online]. Available: http://stereos.com.pl (accessed on Aug 28, 2018) (in Polish).

[9] Wikipedia.[online]. Available: https://en.wikipedia.org/wiki/Anaglyph_3D (accessed on Aug 28, 2018) (in English).

[10] Bernasik, J. (2008). Lectures in photogrammetry and remote sensing. Kraków (in Polish).

[11] Wieczorkowski, K. (1999). Trójwymiarowa wizualizacja komputerowa w zastosowaniach naukowych i edukacyjnych. Neodidagmata, 24, 143-160 (in Polish).

[12] Dylak, S. (1995). Wizualizacja w kształceniu nauczycieli. Poznań: Wydawnictwo Naukowe (in Polish).

[13] Poston, T. \& Serra, L. (1996). Dextrous virtual work. Commun ACM, 39(5), 37-45 (in English).

[14] Bayarri, S., Fernandez, M., \& Perez, M. (1996). Virtual reality for driving simulation. Commun ACM, 39(5), 72-76 (in English).

[15] Jędryczkowski, J. (2008). Prezentacje multimedialne w pracy nauczyciela. Zielona Góra: Oficyna Wydawnicza Uniwersytetu Zielonogórskiego (in Polish).

[16] Postawa, A. (2018). 'Rzeczywistość rozszerzona w nauczaniu i uczeniu się', in Kędzior, J., Krawiec, B., Biedroń, M., \& Mitręga, A. (eds.), Komunikacja a zmiana społeczna. Wrocław: Instytut Pedagogiki Uniwersytetu Wrocławskiego, pp. 109-122 (in Polish).

[17] Liarokapis, F., Mourkoussis, N., White, M., Darcy, J., Sifniotis, M., Petridis, P., Basu, A., \& Lister, P.F. (2004). Web3D and augmented reality to support engineering education. World Trans Eng Tech Educ, 3(1), 11-14 (in English).

[18] Kasworm, C.E. \& Pike, G.R. (1994). Adult undergraduate students: evaluating the appropriateness of a traditional model of academic performance. Res High Educ, 35(6), 689-710 (in English).

[19] Gawlik-Kobylińska, M. (2016). Cztery wymiary uczenia się w projektowaniu scenariusza kursu elearningowego. Zeszyty Naukowe AON, 105(4), 39-52 (in Polish). 


\title{
ТРИВИМІРНА ФОТОГРАФІЯ ЯК ЗАСІБ СТВОРЕННЯ ДИДАКТИЧНИХ ПРЕЗЕНТАЦІЙ
}

\author{
Юліта Маркевіч-Патковська \\ доктор наук \\ WSB Університет у Вроцлаві, м. Вроцлав, Польща \\ ORCID ID 0000-0003-4408-5387 \\ julita.markiewicz-patkowska@wsb.wroclaw.pl \\ Славомір Питель \\ доктор наук \\ Сілезький університет у Катовіце, м. Катовіце, Польща \\ ORCID ID 0000-0002-0886-5151 \\ slawomir.pytel@us.edu.pl
}

\section{Петро Олесневич}

доктор наук, доцент

Університетська школа фізичного виховання у Вроцлаві, м. Вроцлав, Польща

ORCID ID 0000-0002-0426-0630

piotr.olesniewicz@awf.wroc.pl

\section{Кшиштоф Відавський}

доктор наук, доцент

Вроцлавський університет, м. Вроцлав, Польща

ORCID ID 0000-0001-6223-3860

krzysztof.widawski@uwr.edu.pl

\begin{abstract}
Анотація. У 21-му столітті форма представлення інформації з наукових досліджень відіграє надзвичайно важливу роль. Стереоскопія є одним з методів візуалізації, яка протягом останніх років викликає великий інтерес. Численне застосування такої технології спостерігається в різних сферах діяльності: медицині, космічних науках, юридичних науках, маркетингу, індустрії розваг тощо. На думку авторів, стереоскопія може бути також використана для дидактичних цілей. Метою статті $\epsilon$ обговорення процесу створення тривимірної фотографії та можливостей стереоскопії, які дозволяють отримати зображення з ефектом глибини та тривимірності. Автори описують різні способи отримання тривимірних зображень і пристроїв, що застосовуються в цьому процесі, а також методи представлення тривимірного матеріалу більш широкій аудиторії. У статті обговорюються методи вільного перегляду (найдавніший метод перегляду стереоскопічних зображень), анагліф (простий метод, що застосовується під час друкування та відображення статичних зображень і фільмів на екрані), лінзовидний растр (з використанням серії вузьких вертикальних циліндричних лінз) і стереоскопія (де використовуються дзеркала, лінзи, призми або фільтри). Крім того, розглядається застосування комп'ютерних технологій i способи, які дозволяють стереоскопії вигравати у створеному середовищі, використовуючи LCD окуляри 3 активним затвором. Сучасна технологія пропонує значні можливості, водночас підвищуючи вимоги, про які йдеться в статті. Навчання стає більш ефективним, коли інформація отримується через декілька каналів, поєднуючи словесні та візуальні повідомлення. Завдяки 3D-зображенням одержувачі отримують більше інформації, довше іiі запам'ятовують і більше цікавляться змістом повідомлення. Створення дидактичних презентацій з використанням тривимірних фотографій або фільмів представлено як спосіб, який підвищує зацікавленість до навчання, дозволяючи безпосередньо брати участь у пізнавальному процесі, краще сприймати надану інформацію.
\end{abstract}

Ключові слова: тривимірне зображення; ефект глибини; стереоскопія; безкоштовний перегляд; анагліф; лінзовидний растр; дидактична презентація.

\section{ТРЕХМЕРНАЯ ФОТОГРАФИЯ КАК СРЕДСТВО СОЗДАНИЯ ДИДАКТИЧЕСКИХ ПРЕЗЕНТАЦИЙ}

\author{
Юлит Маркевич-Патковски \\ доктор наук \\ WSB Университет во Вроцлаве, г. Вроцлав, Польша \\ ORCID ID 0000-0003-4408-5387 \\ julita.markiewicz-patkowska@wsb.wroclaw.pl
}




\author{
Славомир Пытель \\ доктор наук \\ Силезский университет в Катовице, г. Катовице, Польша \\ ORCID ID 0000-0002-0886-5151 \\ slawomir.pytel@us.edu.pl
}

\title{
Петр Олесневич
}

доктор наук, доцент

Университетская школа физического воспитания во Вроцлаве, г. Вроцлав, Польша

ORCID ID 0000-0002-0426-0630

piotr.olesniewicz@awf.wroc.pl

\section{Кшиштоф Видавски}

доктор наук, доцент

Вроцлавский университет, г. Вроцлав, Польша

ORCID ID 0000-0001-6223-3860

krzysztof.widawski@uwr.edu.pl

\begin{abstract}
Аннотация. В 21-м веке форма представления информации научных исследований играет чрезвычайно важную роль. Стереоскопия является одним из методов визуализации, который в последние годы вызывает большой интерес. Многочисленные применения такой технологии наблюдаются в различных сферах деятельности: медицине, космических науках, юридических науках, маркетинге, индустрии развлечений и тому подобное. По мнению авторов, стереоскопия может быть также использована для дидактических целей. Целью статьи является обсуждение процесса создания трехмерной фотографии и возможностей стереоскопии, которые позволяют получить изображение с эффектом глубины и трехмерности. Авторы описывают различные способы получения трехмерных изображений и устройств, применяемых в этом процессе, а также методы представления трехмерного материала более широкой аудитории. В статье обсуждаются методы свободного просмотра (самый старый метод просмотра стереоскопических изображений), анаглиф (простой метод, который применяется при печати и отображении статических изображений и фильмов на экране), линзовидный растр (с использованием серии узких вертикальных цилиндрических линз) и стереоскопия (где используются зеркала, линзы, призмы или фильтры). Кроме того, рассматривается применение компьютерных технологий и способы, при которых в созданной среде стереоскопия выигрывает, используя LCD очки с активным затвором. Современная технология предлагает значительные возможности, одновременно повышая требования, о которых говорится в статье. Обучение становится более эффективным, когда информацию получают через несколько каналов, сочетая словесные и визуальные сообщения. Благодаря 3D-изображениям получатели получают больше информации, дольше ее запоминают и больше интересуются содержанием сообщения. Создание дидактических презентаций с использованием трехмерных фотографий или фильмов представлено как способ, который повышает интерес к обучению, позволяя непосредственно участвовать в познавательном процессе, лучше воспринимать предоставленную информацию.
\end{abstract}

Ключевые слова: трехмерное изображение; эффект глубины; стереоскопия; бесплатный просмотр; анаглиф; линзовидный растр; дидактическая презентация.

\section{(c) BY-NC-SA}

This work is licensed under Creative Commons Attribution-NonCommercial-ShareAlike 4.0 International License. 